\title{
Pengembangan Metode Integrasi Numerik dengan Frekuensi Batas yang Mampu Mereduksi Pengaruh Sinyal Pengganggu terhadap Hasil Integrasi
}

\author{
Zainal Abidin, Fandi Purnama, dan Budi Heryadi \\ Laboratorium Dinamika, Pusat Rekayasa Industri (PRI), ITB, Bandung \\ Email: za@dynamic.pauir.itb.ac.id
}

\begin{abstract}
ABSTRAK
Dalam pengukuran getaran, proses integrasi sering dilakukan terhadap sinyal percepatan maupun kecepatan getaran. Proses integrasi ini biasanya dilakukan secara numerik dalam DSA (Dynamic Signal Analyzer) sehingga hasil integrasi memiliki nilai penyimpangan terhadap nilai sebenarnya (teoritik). Mengingat seringnya proses ini dilakukan dalam praktik, maka pada makalah ini disajikan metode integrasi numerik dengan frekuensi batas yang telah dikembangkan. Metode ini mampu mereduksi sinyal pengganggu pada hasil integrasi numerik. Untuk menguji kebenaran persamaan integrasi numerik yang telah diperoleh, nilai dari persamaan tersebut perlu divalidasi baik dengan simulasi numerik maupun dengan eksperimen. Berdasarkan hasil validasi ini dapat disimpulkan bahwa persamaan yang telah diperoleh sudah benar.
\end{abstract}

Kata kunci: Metode integrasi, pengukuran getaran, sinyal gangguan.

\begin{abstract}
In vibration measurements, integration process is often performed to acceleration as well as velocity signals. This integration process is usually done numerically in DSA (Dynamic Signal Analyzer) so that the result of integration has error with respect to the true (theoretical) value. Therefore, development of numerical integration methods with cutoff frequency are presented in this paper. This development produces equations which can reduce the influence of noise with respect to the result of numerical integration. Furthermore, these equations are validated with the simulation and experiment results. Base on the validation results, it can be concluded that the equations which have been derrived are correct.
\end{abstract}

Keywords: Integration method, vibration measurement, disturbance signal.

\section{PENDAHULUAN}

Dalam pengukuran getaran, terdapat tiga besaran yang dapat diukur, yaitu simpangan, kecepatan, dan percepatan getaran. Secara matematik, ketiga besaran tersebut memiliki hubungan yang sederhana antara besaran yang satu dengan besaran yang lainnya. Simpangan adalah integral dari kecepatan dan kecepatan adalah integral dari percepatan.

Dalam pengukuran getaran, sering dilakukan proses integrasi dari sinyal pengukuran getaran. Proses integrasi ini dilakukan secara numerik dalam DSA (Dynamic Signal Analyzer) sehingga hasil integrasi yang diperoleh memiliki penyimpangan (kesalahan) terhadap nilai sebenarnya (teoritik) karena metode numerik merupakan metode pendekatan.
Pada penelitian sebelumnya, Abidin dan Purnama [1] telah melakukan analisis kesalahan akibat integrasi numerik pada sinyal pengukuran getaran dengan metode Euler dan trapesium. Selain itu, penelitian lain mengenai kesalahan akibat proses integrasi dan diferensiasi numerik terhadap sinyal hasil pengukuran juga telah dilakukan oleh Zandt [2] sedangkan penelitian lain mengenai pengaruh sinyal pengganggu terhadap hasil integrasi dan diferensiasi sinyal dapat dilihat pada makalah yang dibuat oleh Zandt [2], Thong et al [3], dan Avitabile et al [4].

Penelitian mengenai pengaruh sinyal pengganggu pada umumnya masih berupa analisis kesalahan yang ditimbulkan oleh sinyal pengganggu pada hasil integrasi sinyal. Sementara itu, penelitian mengenai cara mereduksi pengaruh sinyal pengganggu terhadap hasil integrasi sinyal 
masih jarang dilakukan. Bertolak dari masalah tersebut, makalah ini menyajikan metode integrasi numerik dengan frekuensi batas (cutoff frequency) yang mampu mereduksi pengaruh sinyal pengganggu terhadap hasil integrasi sinyal.

\section{METODE PENELITIAN}

Penelitian ini diawali dengan identifikasi masalah yang terjadi, yaitu kesalahan hasil integrasi sinyal akibat adanya sinyal pengganggu. Langkah selanjutnya adalah studi literatur mengenai integrasi sinyal serta literatur lain yang mendukung penulisan analisis penlitian.

Tahap selanjutnya adalah mengembangkan metode integrasi numerik dengan frekuensi batas yang mampu mereduksi pengaruh sinyal pengganggu terhadap hasil integrasi. Pengembangan ini menghasilkan persamaan matematik yang dapat digunakan untuk menentukan pengaruh sinyal pengganggu terhadap hasil integrasi. Untuk meyakinkan bahwa persamaan matematik yang diturunkan sudah benar, maka nilai dari persamaan tersebut divalidasi dengan simulasi numerik dan eksperimen.

\section{HASIL DAN PEMBAHASAN}

\section{Modifikasi FRF dari Fungsi Integrasi Kontinu}

Penurunan persamaan integrasi numerik yang dapat mereduksi pengaruh sinyal pengganggu terhadap hasil integrasi dimulai dengan memodifikasi FRF dari fungsi integrasi kontinu yang dinyatakan dalam Persamaan (1) menjadi FRF dari fungsi integrasi kontinu dengan frekuensi batas (cutoff frequency) yang dinytakan dalam Persamaan (2). Akibatnya, besar FRF dari fungsi integrasi kontinu dengan frekuensi batas $\left(\mathrm{I}_{\mathrm{co}}(\mathrm{j} \omega)\right)$ bernilai konstan untuk $\omega<\omega_{c o}$ dan bernilai sama dengan FRF sebelum dimodifikasi $(\mathrm{I}(\mathrm{j} \omega))$ untuk $\omega>\omega_{c o}$, di mana $\omega_{\text {co }}$ merupakan frekuensi batas. Perbandingan besar kedua FRF ini dapat dilihat pada Gambar 1.

$$
\begin{aligned}
& I(j \omega)=\frac{1}{j \omega} \\
& I_{c o}(j \omega)=\frac{1}{j \omega+\omega_{c o}}
\end{aligned}
$$

\section{Penurunan Persamaan Matematik Fungsi Integrasi Diskrit dengan Frekuensi Batas}

Penurunan persamaan matematik fungsi integrasi diskrit dengan frekuensi batas diawali dengan mentransformasikan fungsi transfer dari fungsi integrasi kontinu dengan frekuensi batas menjadi fungsi transfer dari fungsi integrasi diskrit dengan frekuensi batas. Transformasi ini merupa- kan proses diskritisasi sinyal kontinu a(t) menjadi sinyal diskrit a $(\mathrm{kT})$. Metode-metode diskritisasi yang umum digunakan adalah metode diskritisasi Tustin [5], ZOH (Zero Order Hold) [5], dan MPZ (Matched Poles Zeros) [6]. Dari hasil diskritisasi ini diperoleh tiga fungsi transfer, yaitu fungsi transfer dari fungsi integrasi diskrit Tustin , ZOH, dan MPZ dengan frekuensi batas yang secara berturut-turut dinyatakan dalam Persamaan (3), (4), dan (5).

$$
\begin{aligned}
& I_{c o, T}(z)=\frac{z+1}{\left(\omega_{c o}+\frac{2}{T}\right) z+\left(\omega_{c o}-\frac{2}{T}\right)} \\
& I_{c o, Z}(z)=\frac{\left(1-e^{-\omega_{c o} \mathrm{~T}}\right)}{\omega_{c o}\left(z-e^{-\omega_{c o} \mathrm{~T}}\right)} \\
& I_{c o, M}(z)=\frac{\left(1-\mathrm{e}^{-\omega_{c o} \mathrm{~T}}\right)(\mathrm{z}+1)}{2 \omega_{c o}\left(\mathrm{z}-\mathrm{e}^{-\omega_{c o} \mathrm{~T}}\right)}
\end{aligned}
$$

Selanjutnya, transformasi bilinear dilakukan pada Persamaan (3), (4), dan (5). Dari transformasi bilinear ini diperoleh FRF dari fungsi integarsi diskrit Tustin, $\mathrm{ZOH}$, dan MPZ dengan frekuensi batas. Besar ketiga FRF ini secara berturut-turut dinyatakan dalam Persamaan (6), (7), dan (8) berikut

$$
\begin{aligned}
& \left|I_{\mathrm{co}, \mathrm{T}}(\mathrm{j} \eta)\right|=\frac{1}{\omega_{\mathrm{s}} \sqrt{\left(\pi \mathrm{r}_{\mathrm{co}}\right)^{2}+\tan ^{2}(\pi \mathrm{r})}}, \\
& \left|I_{c o, Z}(j \eta)\right|=\frac{\left(1-e^{-2 \pi \kappa_{c o}}\right) \sec (\pi r)}{\omega_{s} r_{c o} \sqrt{\left(1-e^{-2 \pi \pi_{0}}\right)^{2}+\left(1+e^{-2 \pi k_{0}}\right)^{2} \tan ^{2}(\pi \mathrm{r})}}, \\
& \left|I_{c o, M}(j \eta)\right|=\frac{\left(1-e^{-2 \pi \pi_{c o}}\right)}{\omega_{s} r_{c o} \sqrt{\left(1-e^{-2 \pi \epsilon_{c o}}\right)^{2}+\left(1+\mathrm{e}^{-2 \pi \pi_{0}}\right)^{2} \tan ^{2}(\pi \mathrm{r})}},
\end{aligned}
$$

di mana

$$
r=\frac{\omega}{\omega_{\mathrm{s}}}
$$

dan

$\mathrm{r}_{\mathrm{co}}=\frac{\omega_{\mathrm{co}}}{\omega_{\mathrm{s}}}$.

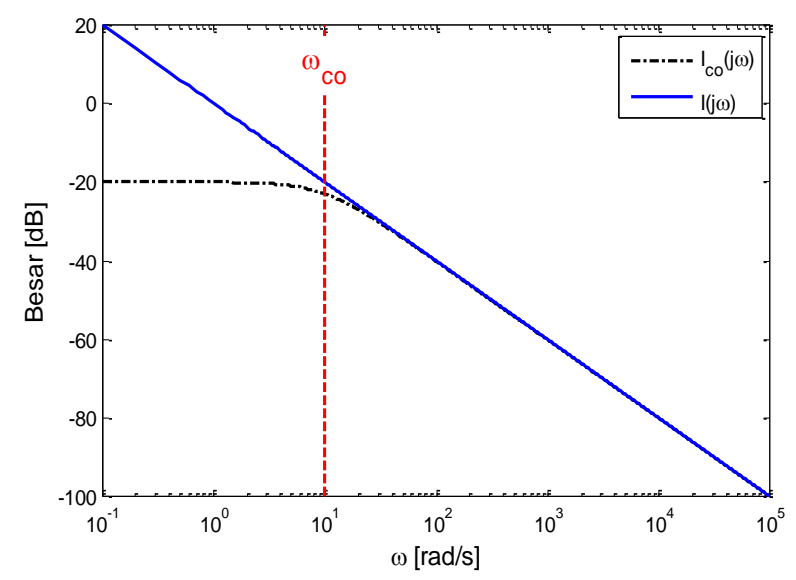

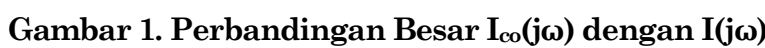


Setelah persamaan matematik besar FRF dari fungsi integrasi dengan frekuensi batas diperoleh, selanjutnya dapat dilakukan analisis kesalahan ampiltudo hasil integrasi diskrit dengan frekuensi batas ( $\mathrm{E}_{\mathrm{I} \text { (c) }}$. Kesalahan ini secara matematik dinyatakan dalam persamaan;

$\mathrm{E}_{\mathrm{Ico}}=\left|\frac{\mathrm{V}_{\mathrm{kon}}-\mathrm{V}_{\mathrm{dis}}}{\mathrm{V}_{\mathrm{kon}}}\right|$,

di mana $V_{k o n}$ merupakan amplitudo sinyal hasil integrasi kontinu sedangkan $\mathrm{V}_{\text {dis }}$ merupakan amplitudo sinyal hasil integrasi diskrit dengan frekuensi batas. Berdasarkan teori FRF, nilai $V_{\text {kon }}$ dan $V_{\text {dis }}$ ini dapat dinyatakan dalam Persamaan (12) dan (13).

$$
\begin{aligned}
& \mathrm{V}_{\mathrm{kon}}=\mathrm{A} \frac{1}{\omega} \\
& \mathrm{V}_{\mathrm{dis}}=\mathrm{A}\left|\mathrm{I}_{\mathrm{co}}(\mathrm{j} \eta)\right|
\end{aligned}
$$

A merupakan amplitudo sinyal yang akan diintegrasikan sedangkan $\left|\mathrm{I}_{\infty}(\mathrm{j} \eta)\right|$ merupakan besar FRF dari fungsi integrasi diskrit dengan frekuensi batas.

Dengan mensubstitusikan nilai-nilai $\left|\mathrm{I}_{\mathrm{co}}(\mathrm{j} \mathrm{\eta})\right|$ untuk untuk masing-masing metode integrasi diskrit dengan frekuensi batas ke dalam Persamaan (13) dan mensubstitusikan Persamaan (12) dan (13) ke dalam Persamaan (11), maka akan diperoleh persamaan kesalahan amplitudo sinyal hasil integrasi diskrit Tustin, ZOH, dan MPZ dengan frekuensi batas yang secara berturut-turut dinyatakan dalam Persamaan (14), (15), dan (16).

$$
\begin{aligned}
& \mathrm{E}_{\mathrm{Ioo}, \mathrm{T}}\left(\mathrm{r}, \mathrm{r}_{\mathrm{co}}\right)=\left|1-\frac{\pi \mathrm{r}}{\sqrt{\left(\pi \mathrm{r}_{\mathrm{co}}\right)^{2}+\tan ^{2}(\pi \mathrm{r})}}\right| \\
& \mathrm{E}_{\mathrm{locZ}}\left(\mathrm{r}, \mathrm{r}_{\mathrm{co}}\right)=\left|1-\frac{\mathrm{r}\left(1-\mathrm{e}^{-2 \pi \kappa_{00}}\right) \sec (\pi \mathrm{r})}{\mathrm{r}_{\mathrm{co}} \sqrt{\left(1-\mathrm{e}^{-2 \pi \kappa_{00}}\right)^{2}+\left(1+\mathrm{e}^{-2 \pi \kappa_{00}}\right)^{2} \tan ^{2}(\pi \mathrm{r})}}\right|
\end{aligned}
$$

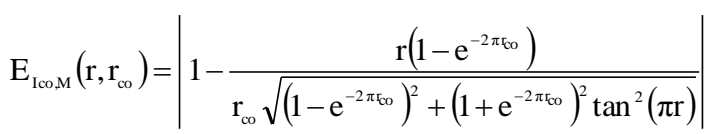

Selain persamaan besar FRF, dari fungsi transfer integrasi diskrit dengan frekuensi batas juga dapat diturunkan persamaan persamaan beda dari fungsi integrasi diskrit dengan frekuensi batas. Persamaan ini diperoleh dengan cara melakukan transformasi z balik terhadap Persamaan (3), (4), dan (5). Hasil dari transformasi ini adalah persamaan beda fungsi integrasi Tustin, $\mathrm{ZOH}$, dan MPZ yang dinyatakan dalam Persamaan (17), (18), dan (19) berikut

$$
\mathrm{v}(\mathrm{k})=\frac{\left(\frac{2}{\mathrm{~T}}-\omega_{\infty}\right) \mathrm{v}(\mathrm{k}-1)+\mathrm{a}(\mathrm{k})+\mathrm{a}(\mathrm{k}-1)}{\left(\frac{2}{\mathrm{~T}}+\omega_{\infty}\right)}
$$

$$
\begin{aligned}
& \mathrm{v}(\mathrm{k})=\mathrm{e}^{-\omega_{\mathrm{co}} \mathrm{T}} \mathrm{v}(\mathrm{k}-1)+\frac{\left(1-\mathrm{e}^{-\omega_{\mathrm{co}} \mathrm{T}}\right)}{\omega_{\mathrm{co}}} \mathrm{a}(\mathrm{k}-1) \\
& \mathrm{v}(\mathrm{k})=\mathrm{e}^{-\omega_{\mathrm{co}} \mathrm{T}} \mathrm{v}(\mathrm{k}-1)+\frac{\left(1-\mathrm{e}^{-\omega_{\mathrm{co}} \mathrm{T}}\right)}{\omega_{\mathrm{co}}}(\mathrm{a}(\mathrm{k})+\mathrm{a}(\mathrm{k}-1))
\end{aligned}
$$

di mana v(k) merupakan fungsi waktu diskrit hasil integrasi dari fungsi waktu diskrit $\mathrm{a}(\mathrm{k})$.

Persamaan matematik lain yang dapat diturunkan adalah persamaan pengaruh sinyal pengganggu terhadap hasil integrasi diskrit dengan frekuensi batas. Pengaruh sinyal pengganggu terhadap hasil integrasi diskrit dengan frekuensi batas $\left(\mathrm{p}_{\mathrm{I}_{\mathrm{co}}}\right)$ didefinisikan sebagai berikut

$$
\mathrm{p}_{\mathrm{I}_{\mathrm{co}}}=\frac{\mathrm{v}_{\mathrm{t}, \mathrm{dis}, \mathrm{RMS}}-\mathrm{v}_{\mathrm{konRMS}}}{\mathrm{v}_{\mathrm{konRMS}}} \text {, }
$$

di mana $\mathrm{v}_{\mathrm{t} \text { dis,RMs }}$ merupakan nilai RMS dari hasil integrasi sinyal utama yang tercemar oleh sinyal pengganggu sedangkan $\mathrm{v}_{\text {konRus }}$ merupakan nilai RMS dari hasil integrasi kontinu sinyal utama yang tidak tercemar oleh sinyal pengganggu. Berdasarkan teori FRF, nilai $\mathrm{v}_{\text {t,dis,RMS }}$ dan $\mathrm{v}_{\mathrm{kon}, \mathrm{RMS}}$ ini dapat dinyatakan secara berturut-turut dalam Persamaan (21) dan (22) berikut:

$$
\begin{aligned}
& \mathrm{v}_{\mathrm{t} \text { dis,RMS }}=\frac{1}{\sqrt{2}} \sqrt{\left.\left(\mathrm{A}_{\mathrm{u}} \mid \mathrm{I}_{\mathrm{co}}(\mathrm{j} \eta)\right)\right)^{2}+\left(\mathrm{A}_{\mathrm{p}} \mid \mathrm{I}_{\mathrm{co}}(\mathrm{j} \eta)\right)^{2}}, \\
& \mathrm{v}_{\mathrm{konRMS}}=\frac{\mathrm{A}_{\mathrm{u}}}{\sqrt{2} \omega_{\mathrm{u}}},
\end{aligned}
$$

di mana $A_{u}$ merupakan amplitudo sinyal utama, $\omega_{u}$ merupakan frekuensi sinyal utama, dan $A_{p}$ merupakan amplitudo sinyal pengganggu. Dengan mensubstitusikan nilai-nilai $\left|\mathrm{I}_{\mathrm{co}}(\mathrm{j})\right|$ untuk masingmasing metode integrasi diskrit dengan frekuensi batas ke dalam Persamaan (21) dan mensubstitusikan Persamaan (21) dan (22) ke dalam Persamaan (20), maka akan diperoleh persamaan pengaruh sinyal pengganggu terhadap hasil integrasi diskrit Tustin, ZOH, dan MPZ dengan frekuensi batas yang dinyatakan secara berturutturut dalam Persamaan (23), (24), dan (25).

$$
\begin{aligned}
& \mathrm{p}_{\mathrm{Ico}, \mathrm{T}}=\pi \mathrm{r}_{\mathrm{u}}\left(\frac{1}{\left(\pi \mathrm{r}_{\mathrm{co}}\right)^{2}+\tan ^{2}\left(\pi \mathrm{r}_{\mathrm{u}}\right)}+\frac{\left(\mathrm{r}_{\mathrm{A}}\right)^{2}}{\left(\pi \mathrm{r}_{\mathrm{co}}\right)^{2}+\tan ^{2}\left(\pi \mathrm{r}_{\mathrm{p}}\right)}\right)^{\frac{1}{2}}-1 \\
& \mathrm{p}_{\mathrm{Ico} Z}=\frac{\mathrm{r}_{\mathrm{u}}\left(1-\mathrm{e}^{-2 \pi \mathrm{roO}_{\mathrm{co}}}\right)}{\mathrm{r}_{\mathrm{co}}}\left(\frac{\sec ^{2}\left(\pi \mathrm{r}_{\mathrm{u}}\right)}{\left(1-\mathrm{e}^{-2 \pi \mathrm{roc}_{\mathrm{co}}}\right)^{2}+\left(1+\mathrm{e}^{-2 \pi \mathrm{roc}_{\mathrm{co}}}\right)^{2} \tan ^{2}\left(\pi \mathrm{r}_{\mathrm{u}}\right)}\right. \\
& \left.+\frac{\left(r_{A} \sec \left(\pi r_{p}\right)\right)^{2}}{\left(1-e^{-2 \pi r_{C O}}\right)^{2}+\left(1+e^{-2 \pi r_{C O}}\right)^{2} \tan ^{2}\left(\pi r_{p}\right)}\right)^{\frac{1}{2}}-1 \\
& p_{\text {Ico }, M}=\frac{r_{u}\left(1-e^{-2 \pi r_{c o}}\right)}{r_{c o}}\left(\frac{\sec ^{2}\left(\pi r_{u}\right)}{\left(1-e^{-2 \pi \pi_{c o}}\right)^{2}+\left(1+e^{-2 \pi r_{c o}}\right)^{2} \tan ^{2}\left(\pi r_{u}\right)}\right. \\
& \left.+\frac{\left(\mathrm{r}_{\mathrm{A}}\right)^{2}}{\left(1-\mathrm{e}^{-2 \pi \mathrm{r}_{\mathrm{CO}}}\right)^{2}+\left(1+\mathrm{e}^{-2 \pi r_{\mathrm{CO}}}\right)^{2} \tan ^{2}\left(\pi \mathrm{r}_{\mathrm{p}}\right)}\right)^{\frac{1}{2}}-1
\end{aligned}
$$


di mana

$r_{\mathrm{A}}=\frac{\mathrm{A}_{\mathrm{p}}}{\mathrm{A}_{\mathrm{u}}}$,

$r_{u}=\frac{\omega_{u}}{\omega_{s}}$

dan

$r_{p}=\frac{\omega_{p}}{\omega_{s}}$.

Di sini, $\omega_{\mathrm{p}}$ merupakan frekuensi sinyal pengganggu.

Pada Gambar 2, 3, dan 4 diperlihatkan pengaruh sinyal pengganggu terhadap hasil integrasi diskrit dengan frekuensi batas untuk ketiga metode integrasi ketika $r_{\mathrm{A}}=0,1$ dan $r_{\mathrm{u}}=0,1$. Dari ketiga gambar ini dapat diungkapkan bahwa pengaruh sinyal pengganggu semakin kecil jika nilai $r_{c o}$ semakin besar (nilai frekuensi batas semakin besar). Selain itu, dapat diungkapkan pula bahwa jika nilai $r_{p}$ semakin kecil (frekuensi sinyal pengganggu semakin kecil) maka pengaruh sinyal pengganggu terhadap hasil integrasi diskrit dengan frekuensi batas akan semakin besar.

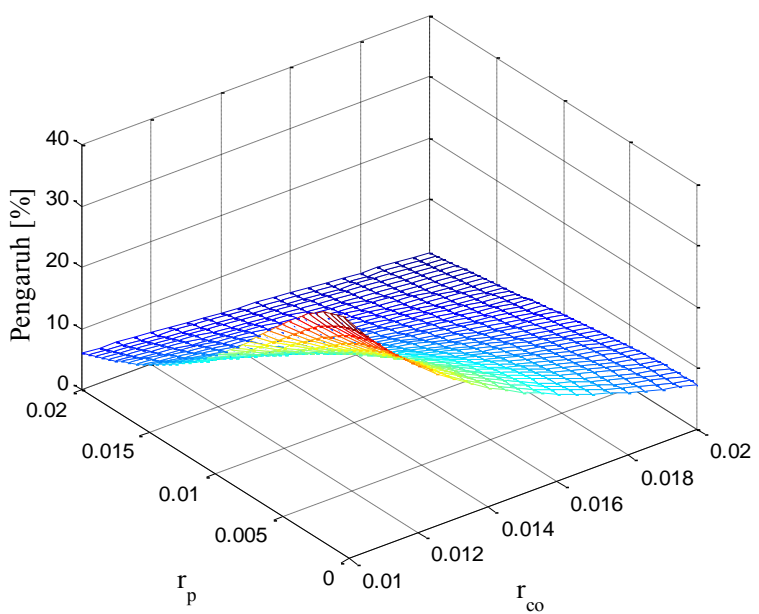

Gambar 2. Hubungan antara $p_{I c o, T}, r_{p}$, dan $r_{c o}$

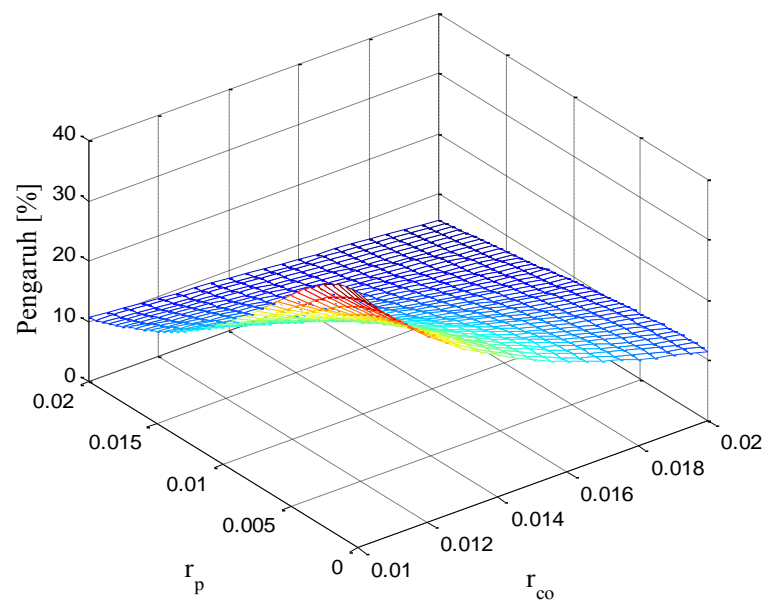

Gambar 3. Hubungan antara pico,Z, $r_{p}$, dan $\mathbf{r}_{c o}$

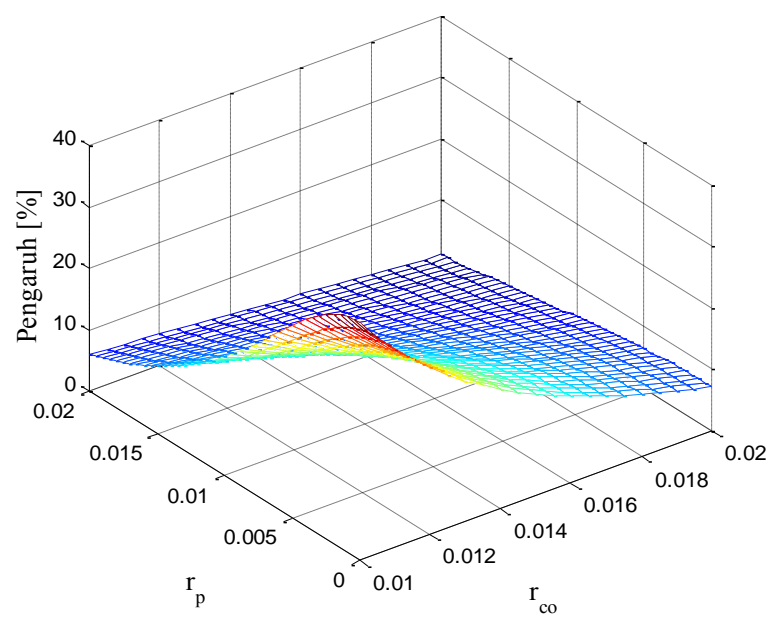

Gambar 4. Hubungan antara $p_{I c o, M}, r_{p}$, dan $r_{c o}$

Validasi Persamaan Kesalahan Amplitudo dan Pengaruh Sinyal Pengganggu terhadap Hasil Integrasi Diskrit dengan Frekuensi Batas

Validasi secara numerik dilakukan dengan cara membandingkan kesalahan amplitudo dan pengaruh sinyal pengganggu yang didapat dari persamaan yang telah diturunkan dengan kesalahan amplitudo dan pengaruh sinyal pengganggu yang didapat dari simulasi dengan menggunakan perangkat lunak MATLAB.

Dalam validasi persamaan kesalahan amplitudo dipilih beberapa parameter sinyal yaitu frekuensi cuplik sebesar $100 \mathrm{~Hz}$ dan amplitudo sinyal yang akan diintegrasikan adalah 10 satuan. Adapun parameter lainnya yang dipilih, diperlihatkan pada Tabel 1.

Tabel 1. Parameter Simulasi Kesalahan Amplitudo Hasil Integrasi Diskrit dengan Frekuensi Batas

\begin{tabular}{ccc}
\hline Kasus & $\mathbf{r}$ & $\mathbf{r}_{\mathbf{c o}}$ \\
\hline 1 & 0,1 & 0,01 \\
2 & 0,1 & 0,02 \\
3 & 0,2 & 0,01 \\
\hline
\end{tabular}

Hasil simulasi ini diperlihatkan pada Tabel 2. Pada tabel ini dapat diungkapkan bahwa nilai kesalahan amplitudo sinyal hasil integrasi yang didapat dari simulasi numerik mendekati nilai kesalahan amplitudo yang dihitung berdasarkan Persamaan (14), (15), dan (16). Hal ini mengindikasikan bahwa persamaan kesalahan amplitudo integrasi diskrit dengan frekuensi batas yang diturunkan sudah benar.

Selanjutnya, validasi persamaan pengaruh sinyal pengganggu terhadap hasil integarsi diskrit dengan frekuensi batas dilakukan dengan beberapa parameter yang dipilih, yaitu frekuensi cuplik sebesar $400 \mathrm{~Hz}$ dan amplitudo sinyal yang akan diintegrasikan adalah 10 satuan. Adapun parameter lainnya yang dipilih diperlihatkan pada Tabel 3. 
Tabel 2. Perbandingan Kesalahan Amplitudo Sinyal Hasil Integrasi Diskrit dengan Frekuensi Batas

\begin{tabular}{clccc}
\hline \multirow{2}{*}{ Kasus } & Metode & Amplitudo & \multicolumn{2}{c}{ Kesalahan [\%] } \\
\cline { 4 - 5 } & Integrasi & [Simulasi] & Persamaan & Simulasi \\
\hline \multirow{4}{*}{1} & Kontinu & 0,159 & 0,000 & 0,000 \\
& Tustin & 0,154 & 3,761 & 3,384 \\
& ZOH & 0,161 & 1,159 & 1,171 \\
& MPZ & 0,154 & 3,792 & 3,415 \\
\hline \multirow{4}{*}{2} & Kontinu & 0,159 & 0,000 & 0,000 \\
2 & Tustin & 0,152 & 5,070 & 4,727 \\
& ZOH & 0,159 & 0,312 & 0,301 \\
& MPZ & 0,151 & 5,191 & 4,847 \\
\hline \multirow{4}{*}{3} & Kontinu & 0,080 & 0,000 & 0,000 \\
& Tustin & 0,069 & 13,600 & 13,481 \\
& ZOH & 0,085 & 6,761 & 6,764 \\
& MPZ & 0,069 & 13,629 & 13,509 \\
\hline
\end{tabular}

Tabel 3. Parameter Simulasi Pengaruh Sinyal Pengganggu

\begin{tabular}{ccccc}
\hline Kasus & $\mathbf{r}_{\mathbf{u}}$ & $\mathbf{r}_{\mathbf{p}}$ & $\mathbf{r}_{\mathbf{A}}$ & $\mathbf{r}_{\mathbf{c o}}$ \\
\hline 1 & 0,1 & 0,010 & 0,1 & 0,02 \\
2 & 0,2 & 0,010 & 0,1 & 0,02 \\
3 & 0,1 & 0,005 & 0,1 & 0,02 \\
4 & 0,1 & 0,010 & 0,2 & 0,02 \\
5 & 0,1 & 0,010 & 0,1 & 0,01 \\
\hline
\end{tabular}

Hasil simulasi ini diperlihatkan pada Tabel 4. Pada tabel ini dapat dilihat bahwa nilai pengaruh sinyal pengganggu terhadap hasil integrasi yang didapat dari hasil simulasi mendekati nilai pengaruh sinyal pengganggu terhadap hasil integrasi yang dihitung berdasarkan Persamaan (23), (24), dan (25). Hal ini mengindikasikan bahwa persamaan pengaruh sinyal pengganggu terhadap hasil integrasi sudah benar.

Tabel 4. Pengaruh Sinyal Pengganggu terhadap Hasil Integrasi Diskrit dengan Frekuensi Batas

\begin{tabular}{clcrr}
\hline \multirow{2}{*}{ Kasus } & Metode & RMS & \multicolumn{2}{c}{ Pengaruh [\%] } \\
\cline { 4 - 5 } & Integrasi & [Simulasi] & Persamaan & Simulasi \\
\hline \multirow{4}{*}{1} & Kontinu & 0,028 & 0,000 & 0,000 \\
& Tustin & 0,030 & 4,935 & 5,891 \\
& ZOH & 0,031 & 9,263 & 10,414 \\
& MPZ & 0,030 & 4,821 & 5,778 \\
\hline \multirow{4}{*}{2} & Kontinu & 0,014 & 0,000 & 0,000 \\
& Tustin & 0,018 & 24,187 & 26,600 \\
& ZOH & 0,020 & 38,978 & 40,099 \\
& MPZ & 0,018 & 24,092 & 24,406 \\
\hline \multirow{4}{*}{3} & Kontinu & 0,028 & 0,000 & 0,000 \\
& Tustin & 0,030 & 6,605 & 7,393 \\
& ZOH & 0,031 & 10,865 & 11,841 \\
& MPZ & 0,030 & 6,496 & 7,284 \\
\hline \multirow{4}{*}{4} & Kontinu & 0,028 & 0,000 & 0,000 \\
& Tustin & 0,037 & 30,425 & 31,547 \\
& ZOH & 0,038 & 33,942 & 35,243 \\
& MPZ & 0,037 & 30,321 & 31,444 \\
\hline \multirow{4}{*}{5} & Kontinu & 0,028 & 0,000 & 0,000 \\
& Tustin & 0,034 & 19,417 & 22,259 \\
& ZOH & 0,036 & 23,429 & 26,802 \\
& MPZ & 0,034 & 19,385 & 22,228 \\
\hline \multirow{2}{*}{} & & &
\end{tabular}

Agar validasi secara eksperimen dapat dilakukan, maka diperlukan data hasil pengukuran getaran. Oleh karena itu diperlukan pengukuran sinyal getaran dari suatu sumber getaran. Dalam penelitian ini, pengukuran sinyal getaran dilakukan pada mesin penyeimbang. Besaran yang diukur adalah kecepatan dan percepatan getaran. Kecepatan getaran diukur dengan menggunakan sensor velocity transducer dan LDV (Laser Doppler Vibrometer) sedangkan percepatan getaran diukur dengan menggunakan dua buah sensor akselerometer yaitu Akselerometer 1 dan Akselerometer 2. Perangkat akusisi data yang digunakan adalah MSA (Multichannel Spectrum Analyzer). Skema pengukuran ini diperlihatkan pada Gambar 5 sedangkan hasil pengukuran getaran diperlihatkan pada Gambar 6.

Selanjutnya, sinyal keluaran Akselerometer 1 diintegrasikan secara numerik menurut Persamaan (17), (18), dan (19). Amplitudo dari hasil integrasi ini dikurangi oleh amplitudo sinyal LDV kemudian dibagi oleh amplitudo sinyal LDV sehingga diperoleh kesalahan amplitudo akibat integrasi diskrit dengan frekuensi batas hasil eksperimen yang kemudian akan dibandingkan dengan kesalahan amplitudo menurut persamaan yang diturunkan. Namun, sebelum perbandingan ini dilakukan, data kesalahan amplitudo yang diperoleh dari eksperimen perlu dipilih terlebih dahulu. Data yang akan dibandingkan adalah data yang nilai frekuensinya sama dengan frekuensi yang ditunjukkan pada Gambar 10. Nilai-nilai frekuensi ini adalah nilainilai frekuensi di mana perbedaan relatif antara amplitudo sinyal LDV dengan amplitudo sinyal velocity transducer kurang dari 3,5\%.

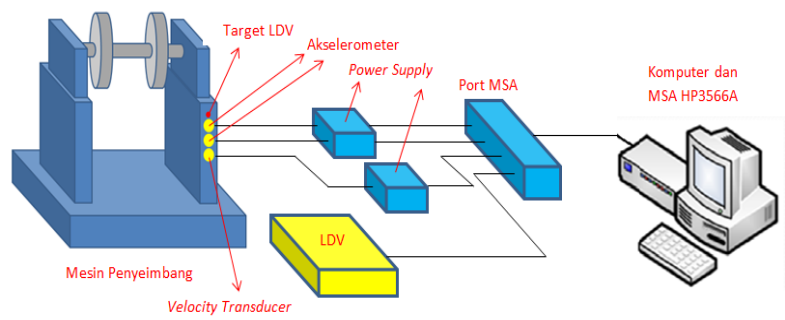

Gambar 5. Skema Pengukuran Getaran pada Mesin Penyeimbang
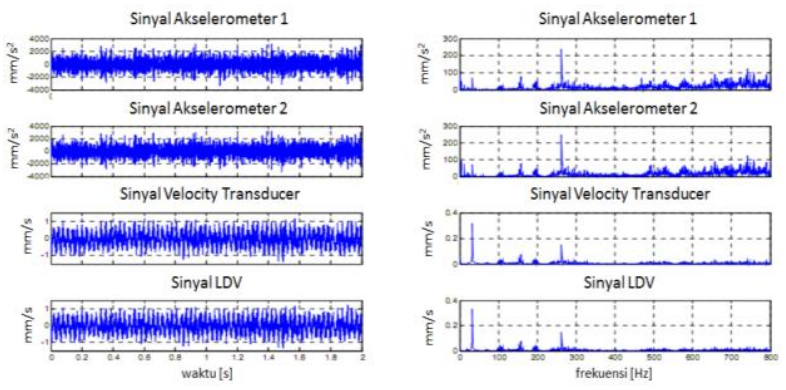

Gambar 6. Data Hasil Pengukuran Getaran 


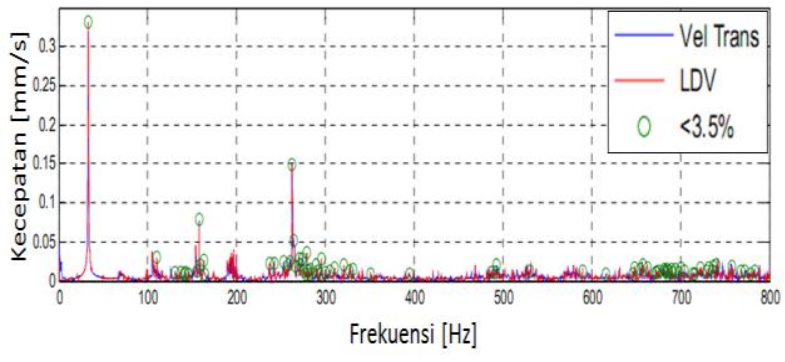

Gambar 7. Letak Frekuensi di mana Perbedaan Amplitudo Spektrum LDV dan Amplitudo Spektrum Velocity Transducer Kurang dari 3,5\%

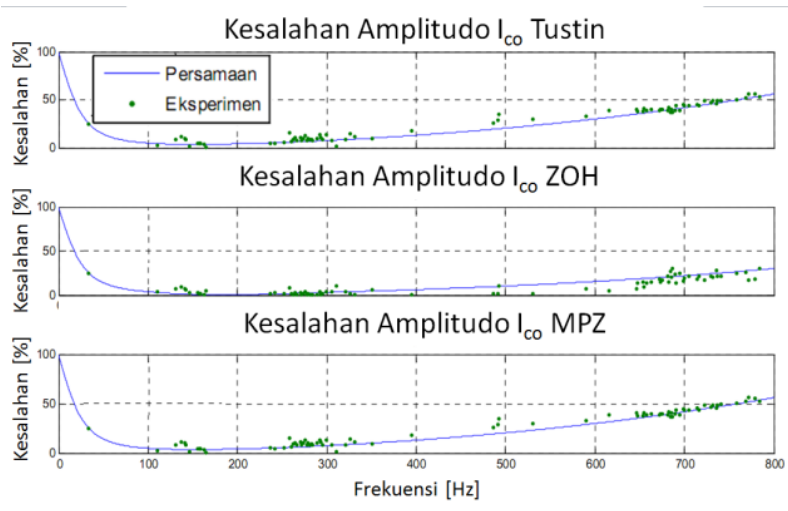

Gambar 8. Kesalahan Amplitudo Hasil Integrasi Menurut Eksperimen dan Persamaan

Pada Gambar 8 diperlihatkan perbandingan antara kesalahan amplitudo hasil integrasi yang diperoleh dari eksperimen dengan kesalahan amplitudo yang dihitung berdasarkan persamaan yang telah diturunkan. Dari gambar ini dapat dilihat bahwa nilai kesalahan amplitudo yang diperoleh dari eksperimen mendekati nilai kesalahan amplitudo yang dihitung berdasarkan persamaan yang telah diturunkan. Hal ini mengindikasikan bahwa persamaan kesalahan amplitudo akibat integrasi diskrit dengan frekuensi batas yang diturunkan sudah benar.

Persamaan lain yang perlu divalidasi secara eksperimen adalah persamaan pengaruh sinyal pengganggu terhadap hasil integrasi diskrit dengan frekuensi batas. Untuk keperluan validasi ini, digunakan kembali data hasil pengukuran getaran seperti yang ditunjukkan pada Gambar 6 .

Untuk menunjukkan kesalahan integrasi akibat sinyal pengganggu, mula-mula sinyal Akselerometer 1 diintegrasikan dengan menggunakan fungsi integrasi numerik konvensional, yaitu fungsi integrasi numerik Euler. Hasil integrasi ini lalu dibandingkan dengan sinyal keluaran velocity transducer dan sinyal keluaran sensor LDV seperti yang diperlihatkan pada Gambar 9. Pada gambar ini tampak bahwa sinyal hasil integrasi numerik Euler sangat jauh berbeda dengan sinyal keluaran velocity transducer. Hal ini disebabkan karena terdapat sinyal pengganggu frekuensi rendah yang mengakibatkan kesalahan hasil integrasi sinyal.
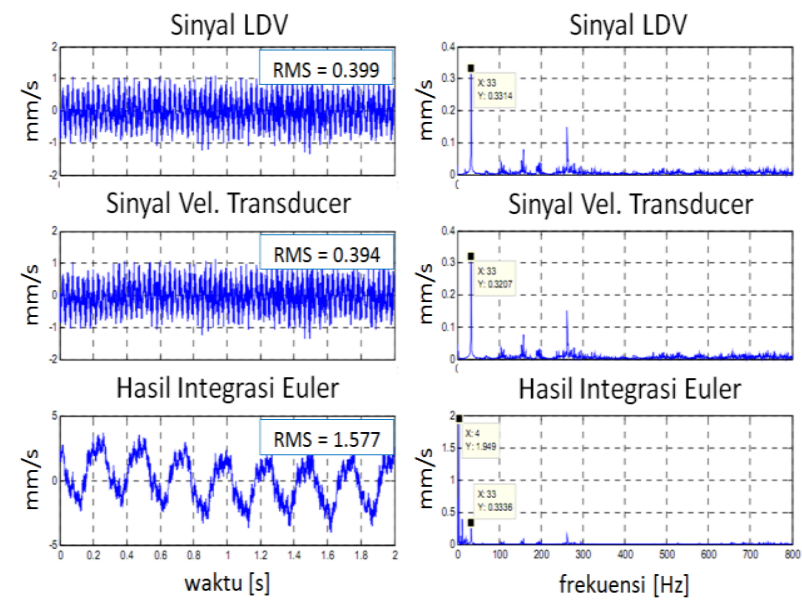

Gambar 9. Perbandingan Sinyal Kecepatan Hasil Integrasi Konvensional dengan Sinyal Keluaran Sensor Kecepatan

Selanjutnya, integrasi dilakukan dengan menggunakan fungsi integrasi diskrit dengan frekuensi batas. Namun, sebelumnya perlu ditetapkan amplitudo dan frekuensi dari sinyal utama dan sinyal pengganggu agar frekuensi batas yang akan digunakan dapat ditentukan. Amplitudo dan frekuensi dari sinyal utama dan sinyal pengganggu yang ditetapkan diperlihatkan pada Gambar 10 .
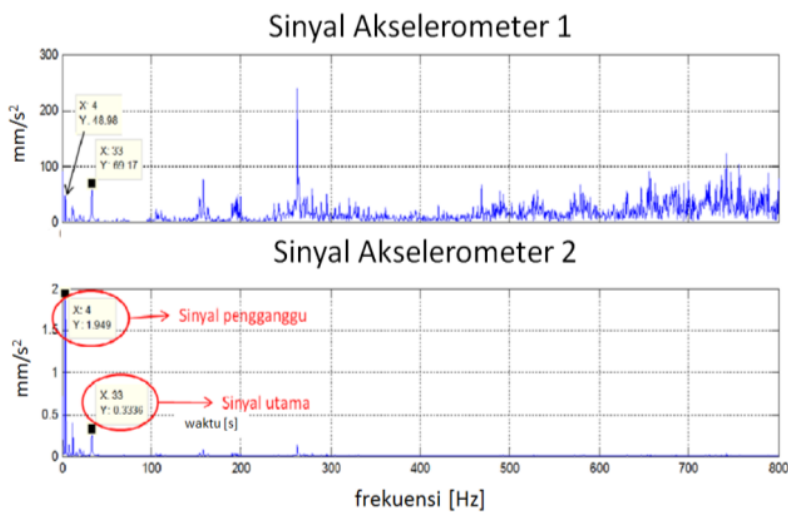

Gambar 10. Penentuan Nilai Amplitudo dan Frekuensi dari Sinyal Utama dan Sinyal Pengganggu

Nilai frekuensi batas ditentukan dengan menggunakan Persamaan (14), (15), (16) dan data amplitudo dan frekuensi sinyal utama dan sinyal pengganggu. Nilai frekuensi batas yang diperoleh untuk ketiga integrasi diskrit dengan frekuensi batas adalah 28,86 $\mathrm{Hz}$ dengan harapan kesalahan yang terjadi kurang dari 10\%.

Selanjutnya sinyal keluaran Akselerometer 1 diintegrasikan dengan menggunakan fungsi integrasi diskrit dengan frekuensi batas. Hasil integrasi ini lalu dibandingkan dengan sinyal keluaran LDV. Perbandingan ini diperlihatkan pada Gambar 11. Pada gambar ini tampak bahwa sinyal hasil integrasi diskrit dengan frekuensi batas relatif sama dengan sinyal keluaran LDV. Hal ini menunjukkan 
bahwa fungsi integrasi diskrit dengan frekuensi batas mampu mereduksi pengaruh sinyal pengganggu terhadap hasil yang diperoleh.

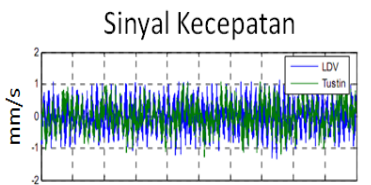

Sinyal Kecepatan

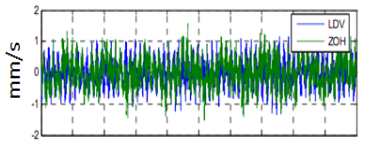

Sinyal Kecepatan

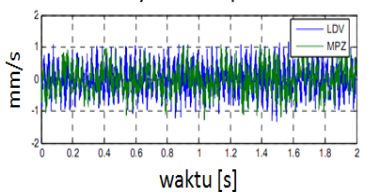

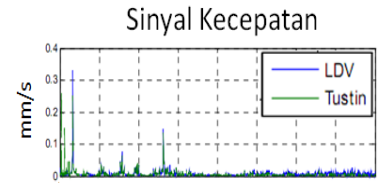

Sinyal Kecepatan

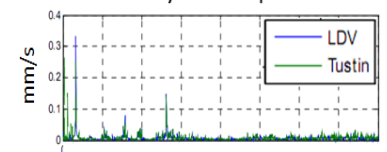

Sinyal Kecepatan

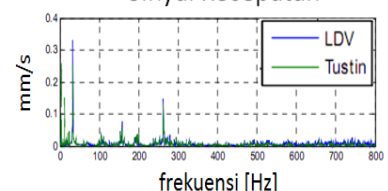

frekuensi [Hz]
Gambar 11. Perbandingan Antara Sinyal Hasil Integrasi Diskrit dengan Frekuensi Batas dan Sinyal Sensor LDV

\section{KESIMPULAN}

Dari penelitian ini, telah berhasil diperoleh metode integrasi yang dapat mereduksi pengaruh sinyal pengganggu terhadap hasil integrasi sinyal. Pengaruh sinyal pengganggu terhadap hasil integrasi diskrit dengan frekuensi batas akan semakin kecil jika nilai frekuensi batas diperbesar.

\section{DAFTAR PUSTAKA}

1. Abidin, Z. dan Purnama, F., Kesalahan Akibat Integrasi Numerik pada Sinyal Pengukuran Getaran dengan Metode Euler dan Trapesium, Jurnal Teknik Mesin, Universitas Kristen Petra, Vol 11, No.1, 2009.

2. Zandt, T. V., Numerical Integration and Differentiation Tutorial, University of Massachusetts Lowell, 2004.

3. Thong, Y. K., Woolfson, M. S., Crowe, J.A., Hayes-Gill, B. R., dan Jones, D. A., Numerical Double Integration of Acceleration Measurements in Noise, Measurement 36, pp. 73-92, 2004.

4. Avitabile, P. dan Hodgkins, J., Numerical Evaluation of Displacement and Acceleration for A Mass, Spring, Dashpot System, Proceedings of the 2004 American Society for Engineering Annual Conference \& Exposition.

5. Leigh, J. R., Applied Digital Control, Prentice Hall, 1992.

6. Lian, F. L., Controller Design of Digital Control Systems, Diktat Kuliah Design of Real-Time Control Systems, National Taiwan University, 2009.

7. Ogata, K., Discrete Time Control Systems, Prentice Hall, 1995. 